\title{
IMMUNOHISTOCHEMICAL EXPRESSION OF NANOG PROTEIN IN PROSTATE CANCER CELLS OF DISTINCT GRADE GROUPS
}

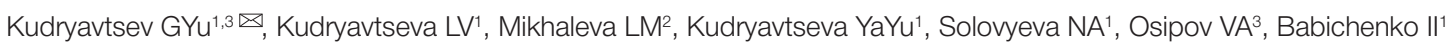

${ }_{1}^{1}$ Peoples' Friendship University of Russia, Moscow, Russia

${ }^{2}$ Research Institute of Human Morphology, Moscow, Russia

${ }^{3}$ Hospital for War Veterans № 2, Moscow, Russia

Prostate cancer is the most common type of cancer among men, which is mainly due to extensive use of screening tests and high total number of prostate biopsies. Verification of tumors with poorer prognosis is the primary goal of prostate cancer management. The study was aimed to determine the clinical and morphological associations and the prognostic value of the Nanog protein expression in prostate cancer of distinct Grade Groups. We used the prostate tissue specimens obtained during surgery, and the biopsy specimens, the total of 89 cases. Histological and immunohistochemical assessment was performed using antibodies to Ki-67 and Nanog. Correlations between the expression of markers and the Grade Groups were revealed using the Spearman's rank correlation coefficient, and the correlation with clinical and morphological characteristics was determined using the chi-squared test $\left(\chi^{2}\right)$. There was a positive correlation between the expression of Ki-67 and Nanog, and the Grade Group numerical order $\left(r_{s}=0.619, p<0.001\right.$ and $r_{s}=0.786, p<0.001$ respectively). We managed to find the relationship between the high Nanog expression and the extraprostatic extension $(p=0.041)$. High expression of Nanog protein in the prostate cancer cells was associated with a higher-grade adenocarcinoma and indicated a poor prognosis.

Keywords: prostate cancer, prostate adenocarcinoma, Ki-67, Nanog, Gleason index, Grade Groups

Author contribution: Kudryavtsev GYu, Kudryavtseva YaYu, Solovyeva NA — literature survey, manuscript writing; Kudryavtseva LV, Osipov VA — statistical data processing; Mikhaleva LM — sample collection and processing; Babichenko II — study concept and design.

Compliance with ethical standards: the study was approved by the Ethics Committee of Medical Institute of the Peoples' Friendship University of Russia (protocol № 13 dated December 19, 2019); the study design was consistent with the Declaration of Helsinki guidelines regarding the research involving identifiable human tissue samples. The informed consent was submitted by all patients.

$\triangle$ Correspondence should be addressed: Georgy Yu. Kudryavtsev

Baikalskaya, 35, apt. 216, Moscow, 107207; kgosha@mail.ru

Received: 06.10.2020 Accepted: 20.10.2020 Published online: 30.10.2020

DOI: $10.24075 /$ brsmu.2020.067

\section{ИММУНОГИСТОХИМИЧЕСКАЯ ЭКСПРЕССИЯ БЕЛКА NАNОG В КЛЕТКАХ РАКА ПРЕДСТАТЕЛЬНОЙ ЖЕЛЕЗЫ РАЗЛИЧНЫХ ПРОГНОСТИЧЕСКИХ ГРУПП}

Г. Ю. Кудрявцев ${ }^{1,3}$, Л. В. Кудрявцева ${ }^{1}$, Л. М. Михалева ${ }^{2}$, Я. Ю. Кудрявцева ${ }^{1}$, Н. А. Соловьева ${ }^{1}$, В. А. Осипов ${ }^{3}$, И. И. Бабиченко

1 Российский университет дружбы народов, Москва, Россия

2 Научно-исследовательский институт морфологии человека, Москва, Россия

${ }^{3}$ Госпиталь для ветеранов войн № 2, Москва, Россия

Рак предстательной железы — наиболее часто выявляемое онкологическое заболевание среди мужчин, этому во многом способствуют распространение скрининговых исследований и высокая частота биопсий органа. Верификация опухолей с потенциально более неблагоприятным прогнозом течения является первостепенной задачей при лечении рака предстательной железы. Целью исследования было определить клинико-морфологические ассоциации и прогностическую значимость экспрессии белка Nanog при раке предстательной железы в различных прогностических группах. Работа выполнена на материале ткани предстательной железы, полученном после оперативного вмешательства, а также образцах ткани биопсии (всего 89 случаев). Было проведено гистологическое и иммуногистохимическое исследование с использованием антител к белкам Кі-67 и Nanog. Корреляционные связи между выраженностью экспрессии указанных маркеров и прогностической группой определяли с помощью коэффициента Спирмена, а связь с клинико-морфологическими проявлениями - с использованием критерия хи-квадрат ( $\left.\mathbf{x}^{2}\right)$. Обнаружена статистически значимая прямая корреляционная связь между выраженностью экспрессии Ki-67 и Nanog и порядковым номером прогностической группы $\left(r_{s}=0,619, p<0,001\right.$ и $r_{s}=0,786, p<0,001$ соответственно). Удалось обнаружить связь между высокой степенью экспрессии Nanog и экстрапростатическим распространением опухоли ( $p$ = 0,041). Повышенная экспрессия белка Nanog в клетках рака предстательной железы связана с более злокачественными формами аденокарциномы и свидетельствует о неблагоприятном прогнозе.

Ключевые слова: рак предстательной железы, аденокарцинома простаты, Кі-67, Nanog, индекс Глисона, прогностические группы

Вклад авторов: Г. Ю. Кудрявцев, Я. Ю. Кудрявцева, Н. А. Соловьева - обзор литературы, написание текста; Л. В. Кудрявцева, В. А. Осипов статистическая обработка данных; Л. М. Михалева - сбор и обработка материалов; И. И. Бабиченко - концепция и дизайн исследования.

Соблюдение этических стандартов: исследование было одобрено Комитетом по этике Медицинского института РУДН (протокол № 13 от 19 декабря 2019 г.), дизайн исследования соответствовал правилам Хельсинкской декларации об использовании тканей человека. От всех пациентов было получено письменное информированное согласие.

$\triangle$ Для корреспонденции: Георгий Юрьевич Кудрявцев ул. Байкальская, д. 35, кв. 216, г. Москва, 107207; kgosha@mail.ru Статья получена: 06.10.2020 Статья принята к печати: 20.10.2020 Опубликована онлайн: 30.10.2020 DOI: $10.24075 /$ vrgmu.2020.067

According to statistics, there were 42,518 newly-reported cases of prostate cancer in the year 2018 in Russia, and the higher incidence rates among males were demonstrated only by tracheal, bronchial and lung malignant neoplasms [1].
Prostate cancer is the most common cancer in men all over the world, the prevalence of the disease in the developed world exceeds 200 cases per 100,000 men. Although the clinical course of the tumor varies from slow-growing localized types 
to highly aggressive cases with fast spreading, the disease is one of the major causes of morbidity and mortality among men $[2,3]$.

The USA is one of the countries with the highest rate of prostate cancer. The disease occurs in one of every six American men during his lifetime. However, only one of those patients actually dies of prostate cancer and its complications, in other patients the tumor usually demonstrates no clinical manifestations [4]. These data were confirmed by autopsy studies in which the postmortem diagnosis of prostate cancer was established in one third of patients aged 50-60, and in $60 \%$ of people who died over the age of 80 [5].

Prior to wide-scale introduction of the prostate-specific antigen (PSA) level assessment, the prostate cancer was often diagnosed after the patients had shown symptoms of locally advanced or metastatic disease, and the overall 5-year relative survival rate was 70\% [6]. The extensive use of PSA screening tests led to a dramatic increase in the prostate cancer detection involving mostly localized cancer. However, the described method does not have high specificity and often contributes to the increased number of invasive procedures in patients with clinically insignificant cancer types [7]. Therefore there is a need to continue search for biological markers in order to refine the various prostate cancer types progression model and choose the appropriate treatment tactics.

The promising strategy to address the problem is the in-debth study of major histogenesis patterns for the most common type of prostate cancer, the adenocarcinoma.

At the current stage, the stochastic model of carcinogenesis suggesting that each individual tumor cell possesses the amplification capacity and is able to produce a new tumor pool is relegated to the background [8]. It is being substituted by hierarchical approach to tumor progression. This approach involves the model in which the tumor consists of atypical cells, polymorphic in their proliferative activity and differentiation potential. The theory described implies that there are cancer stem cells (CSC), which, like normal stem cells, are able to divide indefinitely, inter alia they divide asymmetrically, and therefore they are capable of multipotent differentiation in the tumor tissue. It is believed that cancer stem cells potentiate tumor growth [9].

Early observations (1960s) based on the studies of hemoblastosis proved the heterogeneity of cells in the tumor mass suggesting the existence of immature cell population. The first evidence based on the acute myeloid leukemia research that supported the cancer stem cells (CSC) existence hypothesis was obtained in the 1990s [10]. More recent studies indicated that CSCs were present in tumors of other types, particularly in prostate cancer.

The CSC multipotency maintenance patterns are not well understood, however, the regulatory proteins responsible for similar properties of embryonic stem cells (ESC) may play a vital part.

The Nanog protein is a transcription factor involved in selfrenewal of stem cells. It was first discovered in mouse embryonic stem cells and considered an important transcriptional regulator responsible for cell differentiation [11, 12].

The described protein encoded by the gene NANOG1 consists of 305 amino acids and possesses three functional domains: the $\mathrm{N}$-terminal domain, the $\mathrm{C}$-terminal domain and the conservative homeodomain motif required for binding to promoter region of DNA target regions and transcription regulation [13].

Together with other transcription factors, the most conservative of which are SOX2 and OCT4, Nanog plays a critical role in maintaining ESC properties [14]. These three key factors usually function together through transcriptional network formation to control the expression of a set of pluripotentrelated genes in ESC. High expression of Nanog is observed in the pluripotent stem cells and embryonal carcinoma cells, and its expression is downregulated upon cell maturation [11]. Overexpression of Nanog protein not only contributes to maintenance of ESC pluripotency in murine models in the abscence of such strong extrinsic factors as leukemia inhibitory factor (LIF), but also promotes the human ESC growth in the controlled environment in feeder-free conditions, i.e. in the absence of feeder, the functional basis represented by primary embryonic fibroblasts [15]. Thus, the level of Nanog protein is involved in determining the cell fate in pluripotent cells under physiological conditions.

Identification of cells possessing the stemness-related signs and markers in the tumor tissue might help to predict the unfavourable prostate cancer outcome.

The study was aimed to determine the prognostic value of the Nanog protein expression in the cells of prostate adenocarcinoma.

\section{METHODS}

From September 2017 to May 2019 at two hospitals (City Clinical Hospital № 31 and Hospital for War Veterans № 2) we had been collecting specimens obtained from 89 urological patients during surgery and diagnostic procedures.

The average age of patients at the time of tissue sampling was 69.3 years (47-89 years). Inclusion criteria: prostate cancer patients with morphologically verified diagnosis who received no neoadjuvant therapy. Exclusion criteria: cases with no clinical and instrumental examination data (PSA levels, tumor extension), as well as the cases with tissue amounts insufficient for immunohistochemical analysis and further interpretation of results. Surgery was performed in 48 patients (23 patients underwent transurethral resection, and 25 patients underwent radical prostatectomy), and the diagnostic transrectal multifocal biopsy was performed in 41 patients. Morphological assessment of prostate cancer included not only the cancer grade evaluation according to the Gleason score, but also, according to the WHO recommendations, the Grade Group characteristics were provided in each observation.

Immunohistochemical assessment was carried out according to standard protocol. The rabbit monoclonal Nanog antibody (Clone EPR2027 (2), Epitomics; USA) was used as a primary antibody. The seminomatous testis tissue specimens were used as a positive control. The cell proliferative activity assessment was performed using the anti-Ki-67 rabbit monoclonal antibody (Clone SP6, Cell Marque; USA). The reaction with the tonsils lymphoid tissue (tonsillar germinal center cells) was used as a positive control. Immunohistochemical reaction was carried out using the QUANTO detection system in the Autostainer 360 unit (Thermo Fisher Scientific; USA). The slices were stained with Mayer's hematoxylin. The specimens were examined under the Axioplan 2 imaging miscroscope (Karl Zeiss; Germany) with the AxioCam ERc 5s stand-alone camera (Karl Zeiss; Germany).

Quantification of proliferative activity was performed by counting the percentage of positively stained nuclei per 300 cells at x400 magnification. The following scoring system was used: no expression (score 0), weak expression (score 1) less than $10 \%$ of cell nuclei were stained, moderate expression (score 2) - more than $10 \%$ but less than $33 \%$ of cell nuclei were positive, strong expression (score 3) - more than 33\% of the cell nuclei were positive. 


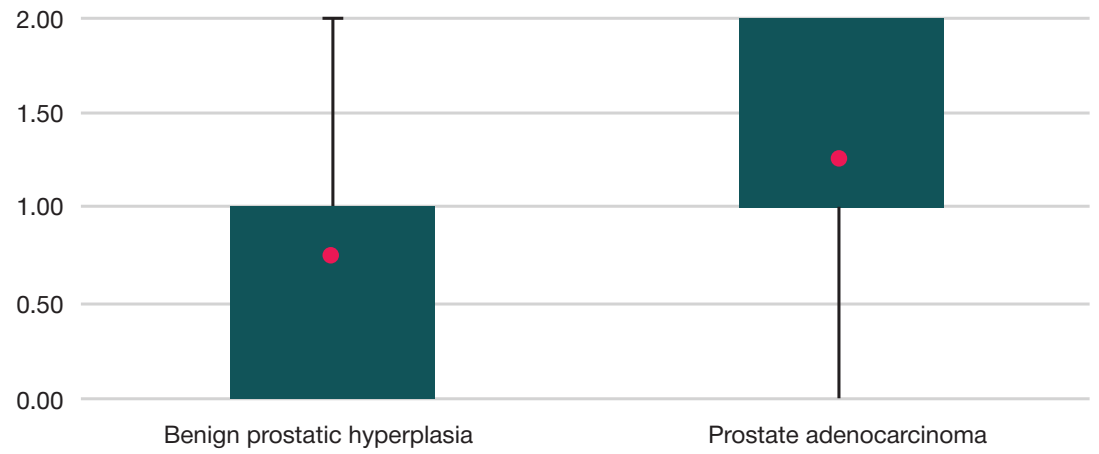

Fig. 1. Expression of Ki-67 in patients with benign prostatic hyperplasia and prostate adenocarcinoma

The Nanog expression assessment was also performed by counting the number of immunopositive cells at high magnification ( $\times 400$, the minimum number of cells was 300 ). However, the results were adjusted for staining intensity. The 0-3 scale was used: 0 was no staining, 1 was weak staining, 2 and 3 were moderate and strong staining respectively. Then the $\mathrm{H}$-score (histochemical score) was calculated using the following formula:

$$
\mathrm{H} \text {-score }=\sum\left(P_{i} \times i\right)
$$

where $i$ was the staining intensity ranged from 0 to 3 , and $\mathrm{P}$ was the proportion of cells stained to different intensities (\%). The $\mathrm{H}$-score value ranged between 0 and 300 [16].

Statistical analysis was carried out using the Statistica 10.0 (StatSoft; USA) software for Windows 10. The significance of differences in the samples was determined using the MannWhitney $U$-test. The differences were considered significant at $p<0.05$. Correlation relationships were determined using the Spearman's rank correlation coefficient, the Chaddock scale was used to evaluate the strength of relationship for correlation coefficients. The chi-square $\left(\chi^{2}\right)$ and Fisher's exact tests were used to reveal correlations between the studied markers expression and the clinical and morphological characteristics of patients.

\section{RESULTS}

After histological examination 68 patients were diagnosed with prostate cancer, the other patients were diagnosed with benign prostatic hyperplasia combined with inflammatory changes of varying severity. In accordance with the recommendations, after morphologic evaluation all observations were distinguished into five prognostic Grade Groups: Grade Group 1 included 18 cases (26.5\%), Grade Group 2 included 16 cases (23.6\%), and Grade Group 3 included 15 cases (22.1\%). Grade Groups 4 and 5 included $10(14.7 \%)$ and $9(13.2 \%)$ cases respectively. The cancer extent was determined based on the clinical and morphological data: tumors detected accidentally during examination, as well as carcinomas limited to the tissue of origin were considered localized cancer (T1 and T2 tumornode-metastasis stage according to AJCC, $8^{\text {th }}$ edition). Extraprostatic extension was considered a sign of advanced cancer (T3 and T4). The serum PSA level of $10 \mathrm{ng} / \mathrm{mL}$ was used as a threshold value.

The expression of Ki-67 was detected in 82 cases (92.1\%). In the group of patients with benign prostatic hyperplasia the expression of $\mathrm{Ki}-67$ was detected in 14 observations
(66.7\%), and in vast majority of cases the expression was weak. Comparison of the described marker expression between groups of patients with benign prostate lesions and prostate cancer revealed significant differences, and the overall proliferative activity in the prostate cancer group turned out to be much higher $(p<0.001)$ (Fig. 1).

Comparison of proliferative activity between different Grade Groups revealed the progressive increase of the mean Ki-67 expression with the Grade Group numerical order (Fig. 2). Correlation analysis revealed strong positive correlation between the parameters compared $\left(r_{s}=0.619 ; p<0.001\right)$.

\section{Expression of Nanog}

In our study no expression of Nanog was detected in patients with benign prostatic hyperplasia, whereas among 68 cases of prostate cancer the 26 specimens (38.2\%) turned out to be Nanog-positive. No expression of Nanog was detected in Grade Group 1, in Grade Group 2 there were three positive cases (18.75\%), in Grade Group 3 there were 6 positive cases (40\%), in Grade Group 4 there were 8 positive cases (80\%), and in Grade Group 5 there were 9 positive cases out of 9 . The mean Nanog expression values adjusted for staining intensity are presented in Fig. 3.

Comparison of $\mathrm{H}$-scores for Nanog expression in the cells of prostate adenocarcinoma made it possible to reveal positive correlation with the Grade Group numerical order $\left(r_{s}=0.786\right.$, $p<0.001)$.

The studied markers expression for the most common Gleason patterns is shown in Fig. 4.

Matching the clinical and morphological properties with the studied markers expression (Table) revealed significant correlation between the Ki-67 expression level and the extraprostatic extension $(p=0.046)$ together with high serum PSA level (> $10 \mathrm{ng} / \mathrm{mL} ; p<0.001)$. At the same time, high $\mathrm{H}$-scores for Nanog expression were associated with advanced cancer $(p=0.041)$. However, no significant correlation between Nanog reactivity and the serum PSA level was observed.

\section{DISCUSSION}

The study of cancer stem cells (CSC) peculiarities made in possible to revise the fundamentals of tumor organization and metabolism. Heterogeneity of tumor cell population is due to hierarchical organization partially modeling the normal histoarchitectonics of the tissue of origin. Symmetric and asymmetric division of CSC contributes both to maintaining the tumor cell population and to tumor volume increase due to loss of stemness by certain cells [17]. 


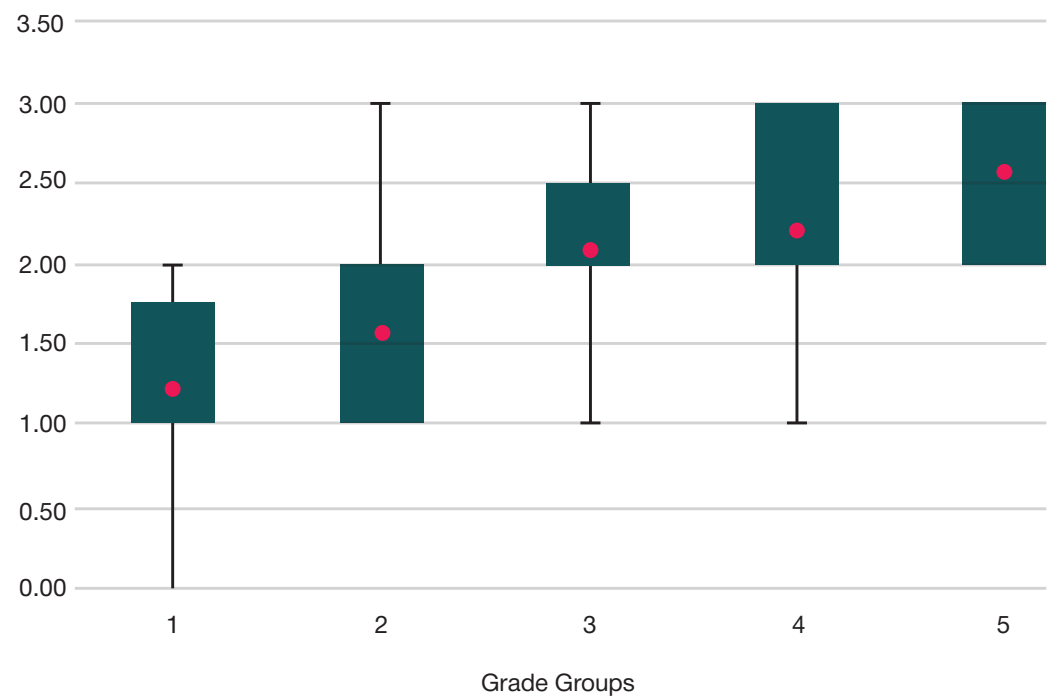

Fig. 2. Comparison of Ki-67 expression between different prostate cancer Grade Groups

It has been shown that in certain cancer types the Nanog expression level in CSC is higher compared to the rest of tumor cell population $[18,19]$.

The functional studies have demonstrated that Nanog is not only the marker of CSC, but is also able to enhance CSC-like properties in some cancer types. For example, the embryonic NANOG gene activation forces the colorectal cancer cell subpopulation to acquire a stem cell-like phenotype [20].

The expression of Nanog was detected in various tumors, including breast cancer, cervical cancer, oral cavity cancer, renal cancer, prostate cancer, lung cancer, gastric cancer, brain cancer and ovarian cancer [21]. High expression of Nanog indicates poor survival prognosis in patients with serous ovarian carcinoma, colorectal cancer and breast cancer. In patients with oral squamous cell carcinoma and lung adenocarcinoma, higher expression of Nanog and Oct4 is associated with advanced stage and worse overall survival [22, 23].

Aberrant expression of Nanog in cancer cells was associated with higher proliferation rate in vitro and tumor growth in vivo. It had been shown that the parallel overexpression of Nanog and Oct4 in the cells of lung adenocarcinoma enhanced clonogenicity and induced the spheroid formation [24], and the Nanog knockdown in the breast cancer cells reduced clonogenicity and cell proliferation [25]. The Nanog knockdown was associated with downregulation of a number of cell-cycle genes (such as cyclins D1, D2, D3 and E1, as well as cyclin-dependent kinases 1 and 6) and the p53 signaling pathway (for example, Bcl6 and Atf3), which could indicate the Nanog involvement in the cell cycle regulation $[25,26]$.

Our study made it possible to identify the Nanog protein expression in the prostate cancer cells. This protein was absent both in normal prostatic tissue and in observations of benign prostatic hyperplasia. The Nanog protein expression heterogeneity suggests that distinct adenocarcinoma variants distinguished primarily by the degree of anaplasia have different histochemical profiles. Considering that this transcription factor is generally inherent in embryonic cells, finding it in the cells of tumor mass speaks well for the theory of specific pool of cells showing signs of "stem-like" phenotype. The comparison of distinct prognostic Grade Groups has revealed that the Nanog expression rate and intensity increases with the growth of the degree of anaplasia. This is reflected by the Gleason score of the tumor and contributes to the Grade Group selection. Such positive correlation confirms that there is a significant subpopulation of CSC, multipotent due to presence of Nanog, in the cell mass of the most poorly differentiated prostate adenocarcinomas. The study also demonstrates the significant correlation between the Nanog expression level and the extraprostatic extension, which is an important factor affecting the outcome. Most observations, which turned out to be considerably immunoreactive for the described protein expression, also showed high expression of Ki-67. That indicated the high proliferative capacity of anaplastic cancer

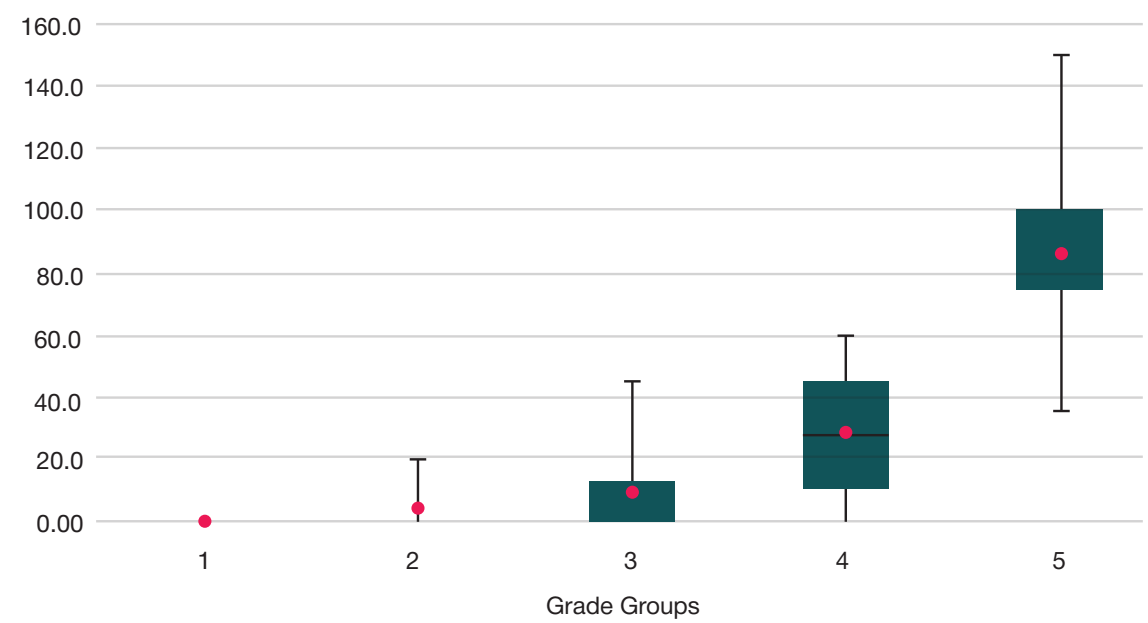

Fig. 3. Comparison of Nanog expression between different prostate cancer Grade Groups 
Ki-67

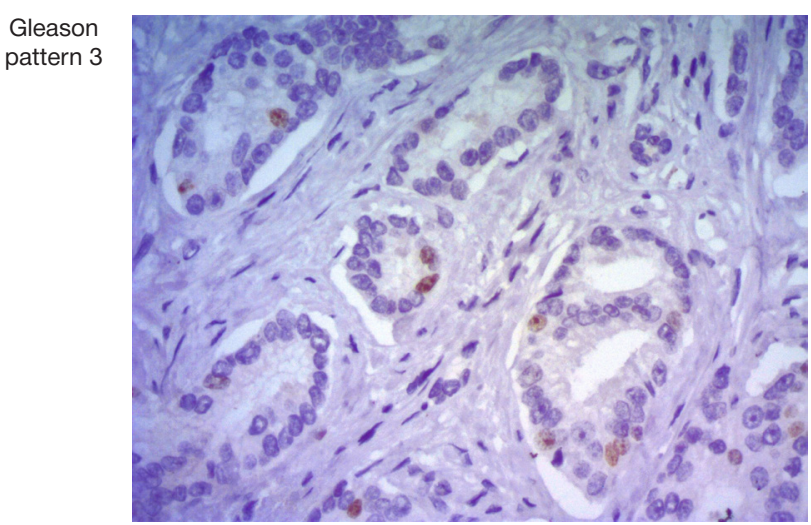

Gleason pattern 4
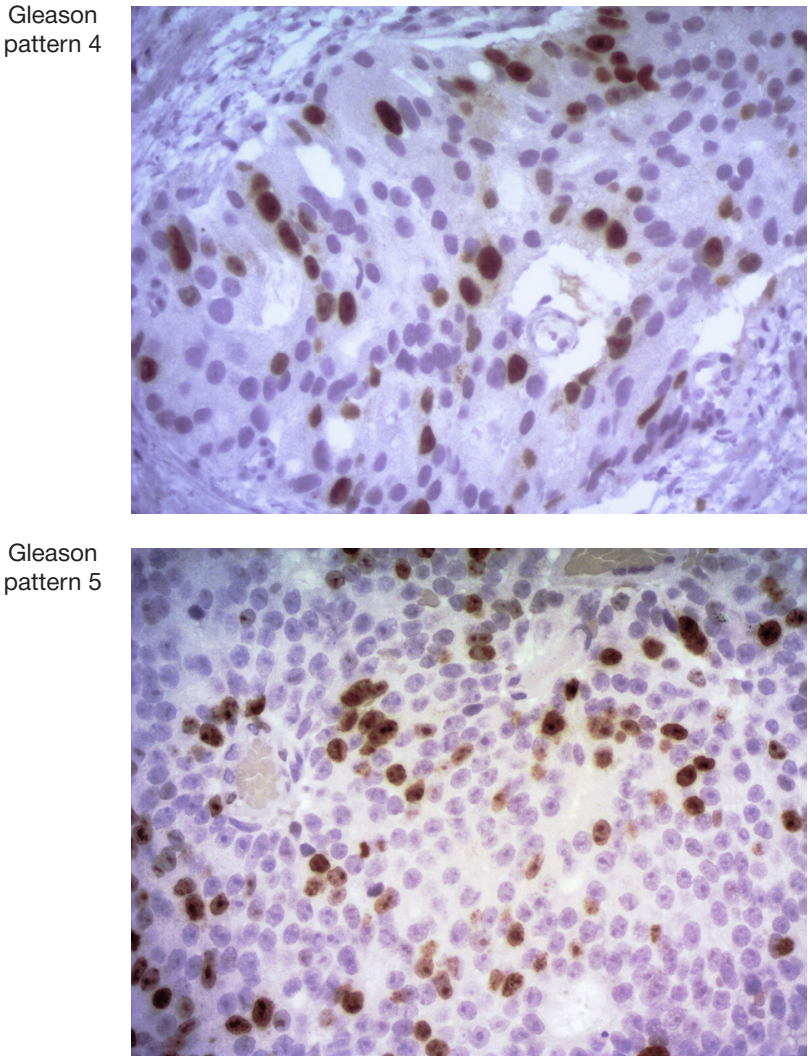

Nanog
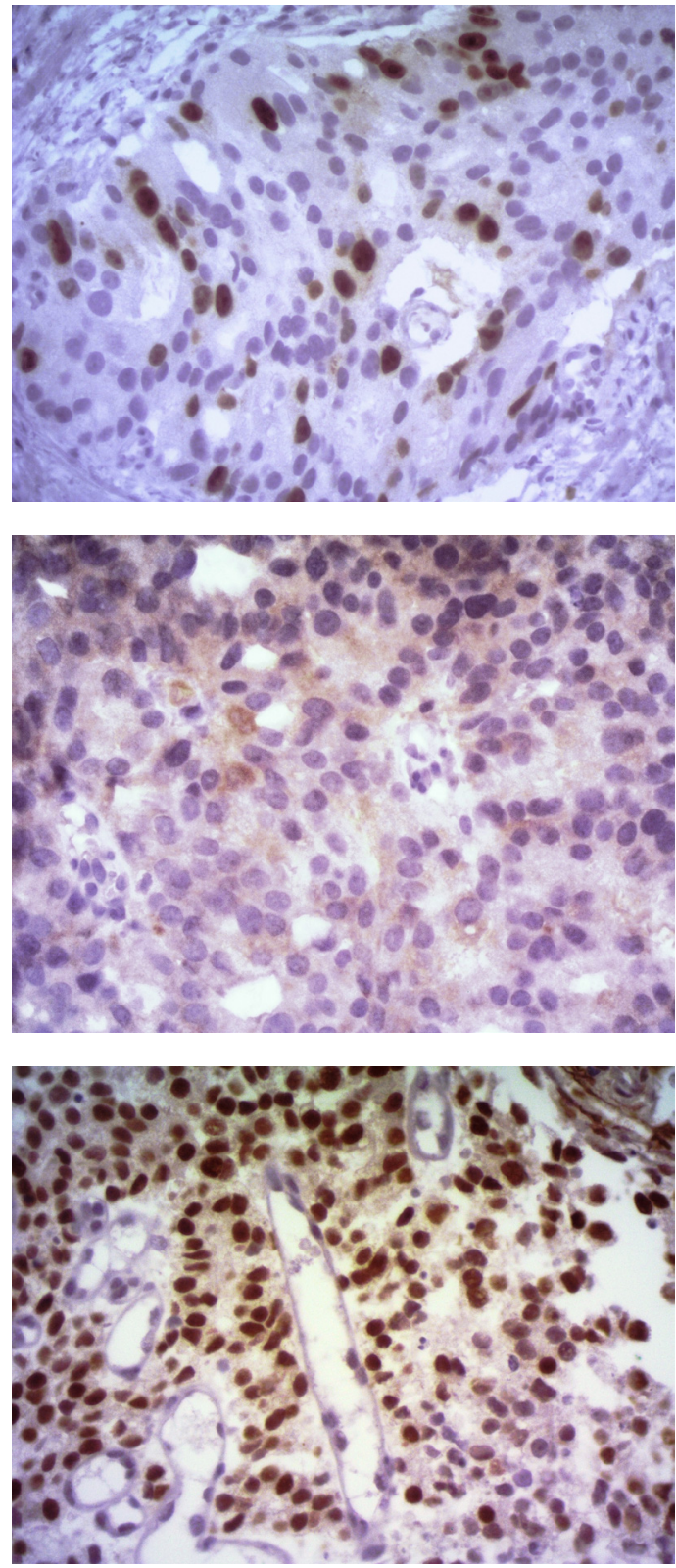

Fig. 4. Expression of Ki-67 and Nanog in the prostate cancer cells for the most common Gleason patterns (magnification $\times 400)$

cells, among them the CSC. Immunohistochemical reaction with markers Nanog and Ki-67 in the Grade Groups 1 и 2 turned out to be much lower compared to Grade Group 5, which indicated the better prognosis in well-differentiated carcinomas.
CONCLUSION

Identification of cancer stem cells in the prostate cancer tissue is a promising diagnosis and outcome prediction method. High expression of Nanog is associated with higher proliferative

Table. Relationship between the expression of Ki-67 and Nanog and the major clinical and morphological characteristics

\begin{tabular}{|c|c|c|c|c|c|c|c|c|}
\hline \multirow{2}{*}{$\begin{array}{l}\text { Clinical and } \\
\text { morphological } \\
\text { characteristics }\end{array}$} & \multirow{2}{*}{$\begin{array}{l}\text { Number of cases, } \\
N(\%), 68 \text { in total }\end{array}$} & \multicolumn{4}{|c|}{ Expression of $\mathrm{Ki}-67$} & \multicolumn{3}{|c|}{ Expression of Nanog (histochemical score) } \\
\hline & & Score 1 & Score 2 & Score 3 & $\begin{array}{l}\text { Significance } \\
\text { level, } p\end{array}$ & Weak $(<40)$ & Strong $(>40)$ & $\begin{array}{l}\text { Significance } \\
\text { level, } p\end{array}$ \\
\hline \multicolumn{9}{|c|}{ Tumor extension } \\
\hline Localized cancer (T1, T2) & $39(57.4 \%)$ & $19(27.9 \%)$ & $17(25 \%)$ & $5(7.4 \%)$ & \multirow{2}{*}{0.046} & $8(11.8 \%)$ & $2(2.9 \%)$ & \multirow{2}{*}{0.041} \\
\hline Advanced cancer $(\mathrm{T} 3, \mathrm{~T} 4)$ & $29(42.6 \%)$ & $6(8.8 \%)$ & $11(16.2 \%)$ & $9(13.2 \%)$ & & $5(7.4 \%)$ & $11(16.2 \%)$ & \\
\hline \multicolumn{9}{|c|}{ PSA level } \\
\hline$<10 \mathrm{ng} / \mathrm{mL}$ & $51(75 \%)$ & $23(33.8 \%)$ & $21(30.9 \%)$ & $4(5.9 \%)$ & \multirow[b]{2}{*}{$<0.001$} & $9(13.2 \%)$ & $5(7.4 \%)$ & \multirow[b]{2}{*}{0.238} \\
\hline$>10 \mathrm{ng} / \mathrm{mL}$ & $17(25 \%)$ & $2(2.9 \%)$ & $7(10.3 \%)$ & $10(14.7 \%)$ & & $4(5.9 \%)$ & $8(11.8 \%)$ & \\
\hline
\end{tabular}


activity and worse prognosis of the tumor. The polypotent cancer stem cells may constitute the source for tumor cell population self-renewal and contribute to metastasis and chemoresistance. The detection of cells possessing such properties requires the selection of more aggressive treatment algorithm aimed primarily at radical tumor removal.

\section{References}

1. Kaprin AD, Starinskiy W, Petrova GV, editors. Malignant tumors in Russia in 2018 (morbidity and fatality). Moscow: FGBU «Moskovskiy nauchno-issledovatel'skiy onkologicheskiy institute im. P.A. Gertsena» - filial FGBU «Natsional'nyy meditsinskiy issledovatel'skiy radiologicheskiy tsentr» Minzdrava Rossii, 2019; 250 p. Russian.

2. Zhou CK, Check DP, Lortet-Tieulent J, Laversanne M, Jemal A, Ferlay J, et al. Prostate cancer incidence in 43 populations worldwide: an analysis of time trends overall and by age group. Int J Cancer. 2016; 138 (6): 1388-400.

3. Heidegger I, Heidenreich A, Pfister D. New biomarkers for selecting the best therapy regimens in metastatic castrationresistant prostate cancer. Target Oncol. 2017; 12 (1): 37-45.

4. Horner MJ, Ries LAG, Krapcho M, Neyman N, Aminou R, Howlader N, et al (eds). SEER Cancer Statistics Review, 19752006, National Cancer Institute. Bethesda, MD. Available from: http://seer.cancer.gov/csr/1975_2006/

5. Bell KJL, Del Mar C, Wright G, Dickinson J, Glasziou P. Prevalence of incidental prostate cancer: a systematic review of autopsy studies. Int J Cancer. 2015; 137 (7): 1749-57.

6. Howlader N, Noone AM, Krapcho M, Miller D, Bishop K, Altekruse SF, et al. SEER Cancer Statistics Review 1975-2013 National Cancer Institute SEER Cancer Statistics Review 1975-2013, National Cancer Institute. National Cancer Institute. Bethesda, 2016. Available from: https://seer.cancer.gov/csr/1975_2014/.

7. Thompson IM, Pauler DK, Goodman PJ, et al. Prevalence of Prostate Cancer among Men with a Prostate-Specific Antigen Level $\leq 4.0$ ng per Milliliter. N Engl J Med. 2004; 350 (22): 2239-46.

8. Kreso A, Dick JE. Evolution of the cancer stem cell model. Cell Stem Cell. 2014; 14 (3): 275-91. DOI: 10.1016/j.stem.2014.02.006.

9. Aguilar-Gallardo C, Simón C. Cells, stem cells, and cancer stem cells. Seminars in Reproductive Medicine. 2013; 31 (01): 005013. DOI: $10.1055 / \mathrm{s}-0032-1331792$.

10. Bonnet D, Dick JE. Human acute myeloid leukemia is organized as a hierarchy that originates from a primitive hematopoietic cell. Nat Med. 1997; 3: 730-7. DOI: 10.1038/nm0797-730.

11. Chambers I, Colby D, Robertson M, Nichols J, Lee S, Tweedie S, Smith A. Functional expression cloning of Nanog, a pluripotency sustaining factor in embryonic stem cells. Cell. 2003; 113: 64355. PubMed PMID: 12787505.

12. Mitsui $\mathrm{K}$, Tokuzawa $\mathrm{Y}$, Itoh $\mathrm{H}$, et al. The homeoprotein Nanog is required for maintenance of pluripotency in mouse epiblast and ES cells. Cell. 2003; 113: 631-42.

13. Gawlik-Rzemieniewska N, Bednarek I. The role of NANOG

\section{Литература}

1. Каприн А. Д., Старинский В. В, Петрова Г. В., редакторы. Злокачественные новообразования в России в 2018 году (заболеваемость и смертность). М.: ФГБУ «Московский научно-исследовательский онкологический институт им. П.А. Герцена» - филиал ФГБУ «Национальный медицинский исследовательский радиологический центр» Минздрава России, 2019; 250 с.

2. Zhou CK, Check DP, Lortet-Tieulent J, Laversanne M, Jemal A, Ferlay J, et al. Prostate cancer incidence in 43 populations worldwide: an analysis of time trends overall and by age group. Int J Cancer. 2016; 138 (6): 1388-400.

3. Heidegger I, Heidenreich A, Pfister D. New biomarkers for selecting the best therapy regimens in metastatic castrationresistant prostate cancer. Target Oncol. 2017; 12 (1): 37-45. transcriptional factor in the development of malignant phenotype of cancer cells. Cancer Biol Ther. 2015; 17 (1): 1-10. DOl:10.108 0/15384047.2015.1121348.

14. Boiani M, Scholer HR. Regulatory networks in embryo-derived pluripotent stem cells. Nat Rev Mol Cell Biol. 2005; 6: 872-84.

15. Gong S, Li Q, Jeter CR, Fan Q, Tang DG, Liu B. Regulation of NANOG in cancer cells. Mol Carcinog. 2015; 54 (9): 679-87. DOI: 10.1002/mc.22340.

16. Hirsch FR, Varella-Garcia M, Bunn PA, et al. Epidermal growth factor receptor in non-small-cell lung carcinomas: correlation between gene copy number and protein expression and impact on prognosis. J Clin Oncol. 2003; 21 (20): 3798-807.

17. Batlle E, Clevers H. Cancer stem cells revisited. Nat Med. 2017; 23 (10): 1124-34. DOI:10.1038/nm.4409.

18. Zhang J, Espinoza LA, Kinders RJ, et al. NANOG modulates stemness in human colorectal cancer. Oncogene. 2013 Sep 12; 32 (37): 4397-405.

19. Niu CS, Li DX, Liu YH, Fu XM, Tang SF, Li J. Expression of NANOG in human gliomas and its relationship with undifferentiated glioma cells. Oncol Rep. 2011; 26 (3): 593-601.

20. Ibrahim EE, Babaei-Jadidi R, Saadeddin A, et al. Embryonic NANOG activity defines colorectal cancer stem cells and modulates through AP1- and TCF-dependent mechanisms. Stem Cells. 2012; 30 (10): 2076-87.

21. Grubelnik G, Boštjančič E, Pavlič A, Kos M, Zidar N. NANOG expression in human development and cancerogenesis. Exp Biol Med. 2020; 245 (5): 456-64.

22. Chiou SH, Yu CC, Huang CY, et al. Positive correlations of Oct4 and Nanog in oral cancer stem-like cells and high-grade oral squamous cell carcinoma. Clin Cancer Res. 2008; 14 (13): 4085-95.

23. Gillis AJ, Stoop $\mathrm{H}$, Biermann $\mathrm{K}$, et al. Expression and interdependencies of pluripotency factors LIN28, OCT3/4, NANOG and SOX2 in human testicular germ cells and tumours of the testis. Int J Androl. 2011; 34 (4 Pt 2): e160-e174.

24. Chiou SH, Wang ML, Chou YT, et al. Coexpression of oct 4 and nanog enhances malignancy in lung adenocarcinoma by inducing cancer stem cell-like properties and epithelial-mesenchymal transdifferentiation. Cancer Res. 2010; 70 (24): 10433-4.

25. Han J, Zhang F, Yu M, et al. RNA interference-mediated silencing of NANOG reduces cell proliferation and induces G0/G1 cell cycle arrest in breast cancer cells. Cancer Lett. 2012; 321 (1): 80-8.

26. Choi SC, Choi JH, Park CY, Ahn CM, Hong SJ, Lim DS. Nanog regulates molecules involved in stemness and cell cycle-signaling pathway for maintenance of pluripotency of P19 embryonal carcinoma stem cells. J Cell Physiol. 2012; 227 (11): 3678-92.
4. Horner MJ, Ries LAG, Krapcho M, Neyman N, Aminou R, Howlader N, et al (eds). SEER Cancer Statistics Review, 19752006, National Cancer Institute. Bethesda, MD. Available from: http://seer.cancer.gov/csr/1975_2006/

5. Bell KJL, Del Mar C, Wright G, Dickinson J, Glasziou P. Prevalence of incidental prostate cancer: a systematic review of autopsy studies. Int J Cancer. 2015; 137 (7): 1749-57.

6. Howlader N, Noone AM, Krapcho M, Miller D, Bishop K, Altekruse SF, et al. SEER Cancer Statistics Review 1975-2013 National Cancer Institute SEER Cancer Statistics Review 1975-2013, National Cancer Institute. National Cancer Institute. Bethesda, 2016. Available from: https://seer.cancer.gov/csr/1975_2014/.

7. Thompson IM, Pauler DK, Goodman PJ, et al. Prevalence of Prostate Cancer among Men with a Prostate-Specific Antigen 
Level $\leq 4.0$ ng per Milliliter. N Engl J Med. 2004; 350 (22): 2239-46. 8. Kreso A, Dick JE. Evolution of the cancer stem cell model. Cell Stem Cell. 2014; 14 (3): 275-91. DOI: 10.1016/j.stem.2014.02.006.

9. Aguilar-Gallardo C, Simón C. Cells, stem cells, and cancer stem cells. Seminars in Reproductive Medicine. 2013; 31 (01): 005013. DOI: $10.1055 / \mathrm{s}-0032-1331792$.

10. Bonnet D, Dick JE. Human acute myeloid leukemia is organized as a hierarchy that originates from a primitive hematopoietic cell. Nat Med. 1997; 3: 730-7. DOI: 10.1038/nm0797-730.

11. Chambers I, Colby D, Robertson M, Nichols J, Lee S, Tweedie S, Smith A. Functional expression cloning of Nanog, a pluripotency sustaining factor in embryonic stem cells. Cell. 2003; 113: 64355. PubMed PMID: 12787505.

12. Mitsui $\mathrm{K}$, Tokuzawa $\mathrm{Y}$, Itoh $\mathrm{H}$, et al. The homeoprotein Nanog is required for maintenance of pluripotency in mouse epiblast and ES cells. Cell. 2003; 113: 631-42.

13. Gawlik-Rzemieniewska N, Bednarek I. The role of NANOG transcriptional factor in the development of malignant phenotype of cancer cells. Cancer Biol Ther. 2015; 17 (1): 1-10. DOI:10.108 0/15384047.2015.1121348.

14. Boiani M, Scholer HR. Regulatory networks in embryo-derived pluripotent stem cells. Nat Rev Mol Cell Biol. 2005; 6: 872-84.

15. Gong S, Li Q, Jeter CR, Fan Q, Tang DG, Liu B. Regulation of NANOG in cancer cells. Mol Carcinog. 2015; 54 (9): 679-87. DOI: $10.1002 / \mathrm{mc} .22340$.

16. Hirsch FR, Varella-Garcia M, Bunn PA, et al. Epidermal growth factor receptor in non-small-cell lung carcinomas: correlation between gene copy number and protein expression and impact on prognosis. J Clin Oncol. 2003; 21 (20): 3798-807.

17. Batlle E, Clevers H. Cancer stem cells revisited. Nat Med. 2017; 23 (10): 1124-34. DOI:10.1038/nm.4409.
18. Zhang J, Espinoza LA, Kinders RJ, et al. NANOG modulates stemness in human colorectal cancer. Oncogene. 2013 Sep 12; 32 (37): 4397-405.

19. Niu CS, Li DX, Liu YH, Fu XM, Tang SF, Li J. Expression of NANOG in human gliomas and its relationship with undifferentiated glioma cells. Oncol Rep. 2011; 26 (3): 593-601.

20. Ibrahim EE, Babaei-Jadidi R, Saadeddin A, et al. Embryonic NANOG activity defines colorectal cancer stem cells and modulates through AP1- and TCF-dependent mechanisms. Stem Cells. 2012; 30 (10): 2076-87.

21. Grubelnik G, Boštjančič E, Pavlič A, Kos M, Zidar N. NANOG expression in human development and cancerogenesis. Exp Biol Med. 2020; 245 (5): 456-64.

22. Chiou SH, Yu CC, Huang CY, et al. Positive correlations of Oct4 and Nanog in oral cancer stem-like cells and high-grade oral squamous cell carcinoma. Clin Cancer Res. 2008; 14 (13): 4085-95.

23. Gillis AJ, Stoop $\mathrm{H}$, Biermann $\mathrm{K}$, et al. Expression and interdependencies of pluripotency factors LIN28, OCT3/4, NANOG and SOX2 in human testicular germ cells and tumours of the testis. Int J Androl. 2011; 34 (4 Pt 2): e160-e174.

24. Chiou SH, Wang ML, Chou YT, et al. Coexpression of oct 4 and nanog enhances malignancy in lung adenocarcinoma by inducing cancer stem cell-like properties and epithelial-mesenchymal transdifferentiation. Cancer Res. 2010; 70 (24): 10433-4.

25. Han J, Zhang F, Yu M, et al. RNA interference-mediated silencing of NANOG reduces cell proliferation and induces G0/G1 cell cycle arrest in breast cancer cells. Cancer Lett. 2012; 321 (1): 80-8.

26. Choi SC, Choi JH, Park CY, Ahn CM, Hong SJ, Lim DS. Nanog regulates molecules involved in stemness and cell cycle-signaling pathway for maintenance of pluripotency of P19 embryonal carcinoma stem cells. J Cell Physiol. 2012; 227 (11): 3678-92. 